\title{
Transgenic Crops and Sustainable Agriculture in the European Context
}

\author{
Luigi Ponti \\ University of California, Berkeley
}

The rapid adoption of transgenic crops in the United States, Argentina, and Canada stands in strong contrast to the situation in the European Union (EU), where a de facto moratorium has been in place since 1998. This article reviews recent scientific literature relevant to the problematic introduction of transgenic crops in the EU to assess if there are specific reasons why transgenic crops have a potentially greater adverse impact on sustainable agriculture in the EU context than elsewhere. Sustainable agriculture integrates three main goals: environmental health, economic profitability, and socioeconomic equity. Transgenic crops do not appear a suitable tool for sustainable agriculture in the EU due to specific environmental, economic, and socioeconomic reasons. Therefore, a moratorium on transgenic crops based on the precautionary principle should be officially adopted until proper risk assessment. In addition, agroecological alternatives to transgenic crops fit better the EU vision of agriculture.

Keywords: transgenic crops deployment in Europe; agricultural biodiversity; participatory technology assessment; precautionary principle; scientific uncertainty

\section{Introduction}

The rapid adoption of transgenic crops in the United States, Argentina, and Canada stands in strong contrast to the situation in the European Union (EU), where a de facto moratorium had been in place since 1998 (Kuiper, Koenig, Kleter, Hammes, \& Knudsen, 2004) and officially ended in May 2004 with the authorization to import transgenic sweet maize (Bt 11, patented by the seed company Syngenta) for food use.
However, Syngenta later said the product would not be commercialized in Europe for now due to strong consumer resistance (Ching, 2004). This delay has infuriated commercial interests in the United States, the main transgenic crops grower, and has led to this country launching a trade suit against the EU over its policy on transgenic crops (Freckleton, Sutherland, \& Watkinson, 2003).

The quasi moratorium on transgenic crops in Europe is based primarily on consumer concerns about the safety of transgenic crops with respect to possible long-term adverse effects on the environment and human health but also on doubts on the sustainability of this new agricultural technology and on the impacts that its adoption might have on global agro-food production and society at large (Hails \& Kinderlerer, 2003). This article reviews recent scientific literature relevant to the problematic introduction of transgenic crops in the EU to assess if there are specific reasons why transgenic crops have a potentially greater adverse impact on sustainable agriculture in the EU context than elsewhere.

The first transgenic organisms were created in the early 1970s using recombinant DNA technology, and the first transgenic plants were produced in 1983; by the late1980s, transgenic crops were on sale in China (virus-resistant tobacco and tomato), but they did not become widespread in the United States until 1994 (Hails \& Kinderlerer, 2003). The most successful transgenic traits to date are herbicide tolerance (soybean, oilseed rape, cotton, and maize) and insect resistance (cotton and maize). Between 1996 and 2003, global area of transgenic crops increased 40 fold, from 1.7 million hectares in 1996 to 67.7 million hectares in 2003. During 2003, transgenic crops were grown in a total of 18 countries; mainly in the United States (63\% 
of global area), Argentina (21\%), Canada (6\%), Brazil (4\%), China (4\%), and South Africa (1\%) (C. James, 2003b).

More than half of the total area currently devoted to transgenic crops is planted to herbicide-tolerant transgenic soybean, and the other major transgenic crops are maize (corn), cotton, and oilseed rape (canola) (Halford, 2004). At present, only a few food crops are permitted for food use and traded on the international food and feed markets, including herbicide- and insect-resistant maize, herbicide-resistant soybeans, oilseed rape, and insect- and herbicide-resistant cotton (primarily a fiber crop, although refined cottonseed oil is used as food), in addition to several varieties of papaya, potato, rice, squash, sugar beet, and tomato approved by government authorities for food use and environmental release (Food and Agriculture Organization/World Health Organization [FAO/WHO] Secretariat, 2004). Transgenic crops are approved for release in some countries, whereas many more countries are wrestling with the issue of how to conduct risk assessments (Heinemann \& Traavik, 2004).

At present, the only significant use of transgenic crops in the EU is the cultivation in Spain of insectresistant maize expressing the insecticidal pro-toxin of the bacterium Bacillus thuringienesis. Major barriers to the use of transgenic crops in the EU are consumer hostility and legislation concerning official approval (Halford, 2004). One of the main determinants of consumer hostility was the lack of a clear labeling policy when transgenic crop products first went on sale in Europe. Therefore, the law now requires any food containing material from transgenic crops and sold in the EU to be labeled. In addition to recent food safetyrelated issues such as mad cow and foot-and-mouth diseases (Arntzen, Coghlan, Johnson, Peacock, \& Rodemeyer, 2003), EU consumers are probably also aware that scientists and manufacturers considered pesticides totally risk free when first marketed in the late 1940s, and data that documented ill effects took nearly 20 years to surface (Marvier, 2000).

There is ongoing debate concerning the possible environmental and human health impacts of growing transgenic crops. Ecologists and other scientists have long expressed concerns about the potential impacts of releasing transgenic crops into the environment (Wolfenbarger \& Phifer, 2000). Existing ecological theory and emerging research data suggest that the planting of transgenic crops can create critical environmental impacts ranging from gene flow, to the rapid development of insect resistance, to impacts on nontarget organisms (Altieri, 2000). Food derived from transgenic crops also poses human health concerns. This was recently confirmed by the broadening of international risk assessment standards to encompass not only health-related effects of food itself (toxicity and allergenicity) but also the indirect effects of food on human health (e.g., potential health risks derived from outcrossing that are specifically related to food derived from transgenic crops) (Haslberger, 2003).

Conflicting assessments and incomplete substantiation of the benefits, risks, and limitations of transgenic food by various scientific, commercial, consumer, and public organizations have resulted in national and international controversy regarding their safe use as food and their safe release into the environment (FAO/WHO Secretariat, 2004). Furthermore, there is growing consensus in Europe that even a rigorous science-based risk assessment of the environmental impact and of possible effects on human health of foods derived from transgenic crops is not sufficient to gain public support for the introduction of this new food production technology because appropriate risk management measures and aspects such as sustainability, benefits, and impact on the society must be taken into account (Kuiper et al., 2004).

\section{Vertical Gene Transfer}

There are two ways in which transgenes can leave transgenic crops: vertical and horizontal gene transfer (van den Eede et al., 2004). Vertical gene transfer is the passage of genetic information from parents to offspring as it occurs in reproduction (e.g., gene flow to wild relatives through and to other nontransgenic crops). Horizontal gene transfer is the transfer of genetic material directly to a living cell or an organism followed by its expression: it has been shown to engage members of the same species, of different species, or even of different domains of life. Gene flow is a potential concern associated with the use of transgenic crops because it could affect genetic diversity of related landraces and wild relatives (Gepts \& Papa, 2003) and because it may compromise the planting of crops by farmers who wish to remain transgenic crops free (e.g., organic farmers) (Haslberger, 2003).

Hybrids between transgenic crops and wild relatives have been documented to be successful in a wide range of cultivated species, with implications on conservation (Frankham, Ballou, \& Briscoe, 2002) and biosafety management (Poppy, 2004). Nonetheless, 
the magnitude and frequency of hybridization in the wild is still an open question, in particular when considering several populations at the landscape level. Using the Beta vulgaris complex as a biological model, a recent study carried out in Northern France showed that weed beets act as relay for gene flow between crops (sugar beet) and to wild populations at a landscape level both by pollen and seeds (Viard, Arnaud, Delescluse, \& Cuguen, 2004). The study provides the first evidence for gene flow between weed and wild individuals of $B$. vulgaris on a regional scale. According to the results of this study, crop-free zones several kilometers wide would be required to prevent transgene escape.

In the United Kingdom, another survey has pointed out that widespread, relatively frequent hybrid formation is inevitable from male-fertile transgenic rapeseed (Wilkinson et al., 2003), in contrast to an earlier regional assessment of hybrid formation where few hybrids were predicted (Rieger, Lamond, Preston, Powles, \& Roush, 2002). This discrepancy highlights the importance of performing risk assessment at the national scale. The study also indicates that physical isolation would tend only to suppress rather than prevent hybrid formation. In fact, it is currently impossible to prevent gene flow between sexually compatible species in the same area because pollen and seeds disperse too easily and too far to make containment practical (Snow, 2002). Similar concerns are particularly relevant for a candidate commercial transgenic crop such as alfalfa (Medicago sativa), which is key to soil fertility in European low-input sustainable agriculture.

Biotech research is being actively conducted in alfalfa, and significant results have been accomplished, with many traits engineered into this crop including glyphosate tolerance (Veronesi \& Rosellini, 2002). Today, alfalfa is the main forage crop in temperate agriculture, and it is widespread in Europe, where this forage legume of ancient origin constitutes the basis of soil fertility through crop rotation. In Mediterranean Europe, alfalfa is a key crop for organic agriculture, providing soil nitrogen and helping with weed control. Because long-distance pollen flow from transgenic alfalfa fields is likely to occur, there is a strong likelihood of contamination of organic alfalfa crops by transgenic crops, which would bring about many commercial and legal problems (Veronesi \& Rosellini, 2002).

Long-distance pollen flow would prevent alfalfa grown with alternative low-input agricultural prac- tices (e.g., organic farming) from coexisting with transgenic alfalfa. Recent European findings on the occurrence of transgene flow in cross-pollinating leguminous species such as birdsfoot trefoil (Lotus corniculatus) confirm scale-dependent effects of transgene dissemination (Marchis, Bellucci, Arcioni, $\&$ de Marchis, 2003). In fact, as the size of the recipient "sink" plot and of the transgene source plot increased, the degree to which gene flow occurred also increased, making it difficult to effectively prevent gene flow in real agricultural fields. These results are corroborated by previous studies on alfalfa (St. Amand, Skinner, \& Peaden, 2000) and oilseed rape (Brassica napus) (Rieger et al., 2002) in which gene flow is shown to be strongly affected by field size.

Because the size of the pollen source and of the recipient populations influences the frequency of transgene flow, scale-dependent effects of transgene dissemination are even more serious concerns in the perspective of a worldwide trend to large-scale transgenic monocultures. Requiring minimum isolation distance of 1,557 meters, complete containment of transgenes within alfalfa seed or hay production fields would be highly unlikely under current production practices in Europe (St. Amand et al., 2000). Furthermore, a wide variety of ancestors of alfalfa as well as botanically related wild species are present in Europe, greatly increasing the risk of gene flow from transgenic alfalfa to wild relatives (Istituto Nazionale di Ricerca per gli Alimenti e la Nutrizione \& Ministero delle Politiche agricole e Forestali, 2004). There are also wind-pollinated transgenic crops that have sexually compatible wild relatives in Europe: in this case, the extent of gene flow at the landscape level is dramatic.

Gene flow on a landscape level has also been documented for creeping bentgrass (Agrostis stolonifera) in a recent field study (Watrud et al., 2004). This species is the most common grass in golf greens but also a naturally occurring plant throughout Europe. It was one of the first wind-pollinated, perennial, and highly outcrossing transgenic crops being developed for commercial use. Based on seedling progeny survival after spraying with the specific herbicide and molecular assays, Watrud et al. showed that gene flow from transgenic creeping bentgrass occurred up to 21 kilometers. The authors also acknowledged that a fully effective, long-term containment of transgenes is unlikely. A growing body of evidence on gene flow at a landscape level is thus reinforcing the need for strategies of transgene containment. 
Several strategies have been proposed for creating transgenic cultivars from which transgene escape to wild relatives would seem unlikely, but a recent analysis showed that none of these strategies would be failsafe (Haygood, Ives, \& Andow, 2004). Even with a leakage parameter as small as $10^{-3}$, the probability of escape within as few as 10 generations could be appreciable. This finding, together with the evidence of gene flow even at a regional level, is in direct contrast with European rural development policies such as ecological networks, which have been implemented (e.g., Life ECOnet project) as a mechanism whereby a holistic, integrated, and long-term approach to regional and subregional sustainable development can be promoted in Europe (P. James, Ashley, \& Evans, 2000). Environmental networks would facilitate gene flow at the landscape level, making transgene containment strategies even more ineffective.

Ecological networks are key elements of biodiversity in the European agricultural landscape. Such networks are made of uncultivated landscape features that influence crops through intercommunity exchanges of organisms, materials, and energy, providing vital ecosystem services to European agricultural systems (Altieri, Nicholls, \& Ponti, 2003). Ecological networks are being defined and realized throughout Europe (P. James et al., 2000): They can be seen as a network of key natural habitats, buffer zones, and nature restoration areas connected by ecological corridors to facilitate movement and survival of species through the landscape. Ideally, an ecological network is a framework for a sustainable rural development because it extends key ecological services provided by natural habitats to the entire productive landscape via a network of noncrop areas.

One of the aims of ecological networks is to reduce negative impact of habitat fragmentation on insect movement and associated pollen flow between plant populations by introducing a network of natural habitats. In a study recently carried out in Europe on forests as potential landscape barriers for foraging insect pollinators (Kreyer, Oed, Walther-Hellwig, \& Frankl, 2004), bumblebee workers were found foraging at distances of up to 2.2 kilometers from their nests, and some individuals were able to cross 600 meters of forestland between floral mass resources. The authors specifically warned against experiments with genetically modified crop species with potential bumblebee pollination (e.g., oilseed rape, Brassica napus) in which an isolating effect of forests is assumed. In addition to the extent to which gene flow occurs, some studies are providing insight on the potential risk associated with the escape of transgenes.

In France, risk assessment studies of transgenic crops have recently brought evidence of a low spontaneous hybridization frequency of oilseed rape with the weed Raphanus raphanistrum (Guéritaine, Bazot, \& Darmency, 2003). $R$. raphanistrum is a less widespread weed than the common Sinapis arvensis because it grows only in acidic soils, but yet it is harder to eradicate using herbicides than other Brassica weed species. First-generation hybrids were shown to be able to establish and flower, thus potentially producing backcrossed progeny with restored fitness, which can be the critical link for gene flow between the crop and the weed. A transgene conferring herbicide resistance (like the one carried by herbicide-tolerant oilseed rape) could provide hybrids with a high survival value when herbicide is sprayed, potentially leading to the emergence of "super weeds" in Europe.

Stable expression of a transgene may lead to increased fitness for wild plants after acquiring the transgene via crop-weed hybridization also in the case of insect-resistant transgenic crops. Recently, the gene coding for the insecticidal toxin of $\mathrm{B}$. thuringiensis was successfully transferred to interspecific first-generation hybrids between three accessions of Brassica rapa and nine Bt-expressing lines of Brassica napus (Zhu et al., 2004). The expression of the toxin was successfully transferred also to successive backcross generations, an indication that the Bt gene can persist and be stably expressed in wild $B$. rapa, increasing the fitness of this weed.

Assessing the risks associated with gene flow from transgenic crops to wild relatives is a significant scientific challenge. However, most researchers have focused on assessing the frequency of gene flow, too often on a localized scale, and ignored the hazards caused by gene flow (Poppy, 2004). Quantitative risk assessment defines the risk as a function of hazard and exposure, but for impacts on nontarget organisms, the emphasis has been mainly on hazard, whereas for gene flow the focus has been mainly on measuring frequencies (exposure) rather than consequences of occurrence. To fill this gap, more multidisciplinary research is needed (Poppy, 2004).

\section{Horizontal Gene Transfer}

The majority of studies addressing potential risks of transgenic crops have addressed only aboveground effects. However, recent methodological advances in 
soil microbial ecology have allowed research focus to try to gain knowledge of the effects of transgenic crops on soil microbial communities and processes, which are essential to key terrestrial ecosystem functions (Bruinsma, Kowalchuk, \& van Veen, 2003). Recent findings show that transgenes can be transferred to native soil microorganisms through horizontal gene transfer; in addition, novel proteins have been shown to be released from transgenic plants into the soil ecosystem, thus potentially influencing the biodiversity of the microbial community by selectively stimulating the growth of organisms that use such proteins (Dunfield \& Germida, 2004). In Italy, insecticidal toxins produced by Bacillus thuringiensis (the same toxins expressed in insect resistant transgenic corn) were shown to enhance persistence in soil of glyphosate and glufosinate-ammonium herbicides under laboratory conditions (Accinelli, Screpanti, Vicari, \& Catizone, 2004). This indicates that transgenic crops have the potential to impact soil microbial communities.

Although long-term effects of transgenic crops on soil functioning and biodiversity are difficult to predict and still remain unknown (Brooks et al., 2003), even minor alterations in the diversity of the microbial community could affect soil health and ecosystem functioning (Dunfield \& Germida, 2004). A recent analysis pointed out the following two major implications of horizontal transgene transfer to soil microorganisms (Heinemann \& Traavik, 2004): (a) Horizontal gene transfer from transgenic plants to microbes could still have an environmental impact at a frequency approximately a trillion times lower than the current risk assessment literature estimates the frequency to be, and (b) current methods of environmental sampling preclude measuring horizontal gene transfer with the sensitivity necessary to dismiss eventual environmental harm. In fact, horizontal gene transfer binds the microbial community into a complex network, allowing alleles of genes to evolve on a global scale even at intuitively low frequencies of transfer $\left(\leq 10^{-17}\right)$.

Another fact that increases concerns on horizontal gene transfer is that most of the transgenic crops approved for use carry the neomycin phosphotransferase II gene, which confers resistance to the antibiotics kanamycin and neomycin. This causes controversy and intense debate because (a) clinical therapy is likely to be compromised due to inactivation of the oral dose of the antibiotic from consumption of food derived from transgenic crops, and (b) there is risk of gene transfer from plants to gut and soil microorganisms or even to consumers' cells (Jelenic, 2003).
As recent results suggest, ingested transgenic corn DNA and B. thuringiensis toxin are not totally degraded in the gastrointestinal tract of mammalians (Chowdhury et al., 2003). Despite insufficient information about the fate of genetically modified DNA and protein in vivo, transgenic corn has been approved as an animal feed in several countries.

\section{Development of Insect Resistance}

The European corn borer is the main insect pest of maize in Europe and, as already mentioned, transgenic corn varieties have been developed that produce the insecticidal toxin of the bacterium $B$. thuringiensis. This generates a pressure for the selection of resistance mechanisms in insect pest populations and requires the development of management strategies to delay the appearance of resistance to these insecticidal toxins. Usually some refuge nontransgenic crop is maintained close to the transgenic field to decrease the chances of possible resistant pests to mate with each other, thus avoiding the selection of resistance alleles. It has also been suggested that wild hosts and other crops could serve as part of a larger refuge strategy. However, recent data from Europe indicate that adults emerging from noncrop refuges (i.e., the weed mugwort) would not be useful for managing the evolution of resistance to the $\mathrm{B}$. thuringiensis toxins in European corn borer populations (Martel, Rejasse, Rousset, Bethenod, \& Bourguet, 2003).

Spatial scale seems to matter also in predicting environmental impacts of insect-resistant transgenic crops. This would make field trials inadequate for evaluating risk of a regional deployment of such transgenic plants. Models of the evolution of insect resistance to transgenic crops have often assumed that population size is infinite or that carrying capacity is fixed. Recently, the effects of population size on resistance evolution were evaluated in insect-resistant transgenic cotton (Sisterson, Antilla, Carriere, Ellers-Kirk, \& Tabashnik, 2004), showing that time to resistance decreases as region size increases. This occurs because larger regions are more likely to have at least one field in which resistance evolves rapidly and serves as a source from which resistance can spread throughout the region.

Moreover, most previous work on gene flow from transgenic crops has emphasized potential effects of transgene movement on wild relatives of crops, landraces, and organic plantings, whereas implications for pest resistance have been largely ignored. Recent 
research has shown that variable Bt toxin production in seeds of refuge plants due to gene flow undermines the refuge strategy and could accelerate pest resistance to Bt crops (Chilcutt \& Tabashnik, 2004).

\section{Impacts on Nontarget Organisms}

As commercially available insect-resistant transgenic crops only contain genes coding for a toxin produced by the bacterium $B$. thuringiensis, in this case risk assessment crops focuses on the impacts of this toxin. However, assessment of the risks from Bt crops should not be based solely on toxicological studies that examine direct effects of $\mathrm{Bt}$ toxins on potential nontarget organisms but rather on a broader ecological assessment of nontarget effects of Bt crops based on the dispersal of transgenic corn pollen and potential trophic-level effects on natural enemies (Obrycki, Losey, Taylor, \& Jesse, 2001)

Multitrophic aspects of insect-resistant transgenic crops are poorly understood. Most of the studies on the environmental impacts of insect-resistant transgenic crops have concentrated on natural enemies of target herbivores, but natural enemies may come into contact with $\mathrm{Bt}$ toxins also via nontarget herbivores and in a more severe way. This happens because the toxins do not bind to receptors on the midgut membrane in nontarget herbivores (Groot \& Dicke, 2002). With the development of a new generation of Bt crops with much higher expression levels of the toxin, the effects on nontarget organisms reported so far are likely to be an underestimate.

Given their limited benefits for insect management (Obrycki et al., 2001), their documented ecological effects on nontarget species, and their largely unknown, potentially underestimated effects on nontarget organisms (Groot \& Dicke, 2002), insectresistant transgenic crops seem to have a minor role in the toolbox of a sustainable pest management. Transgenic crops possess several attributes that require modification of existing and widely inconsistent models for assessing the environmental risks to nontarget species (Andow \& Hilbeck, 2004). This implies that risk assessment methodologies for nontarget effects of transgenic crops are currently inadequate.

Even if transgenic crops provided a new dimension of control over pests, diseases, and weeds, this would occur in a poorly targeted way, and they would drive agriculture further toward monoculture and the excessive control of the agricultural environment (Dale, Clarke, \& Fontes, 2002). In this scenario, control would be exploited primarily to maximize crop productivity at the expense of supporting a diversity of wildlife food chains (e.g., those of insects, seeds, weeds, or birds) and habitats in the environment. Transgenic crops have therefore a high potential to reduce agricultural biodiversity in the future (St. Amand, 2004).

\section{Transgenic Crops and Biodiversity}

A fundamental problem in predicting changes in ecological systems is that the scale at which we can observe such systems is less extensive than the scale over which we wish to make predictions. Given the current debates concerning the likely large-scale impacts of the introduction of transgenic crops, predictions of impacts on biodiversity over time periods of decades or more are required at nationwide spatial scales (Freckleton, Stephens, Sutherland, \& Watkinson, 2004). Recently, an impressive farm scale study was conducted in the EU to address issues of possible impact of transgenic crops on biodiversity.

The Farm Scale Evaluation (FSE; Firbank, 2003) was carried out in the United Kingdom to test the hypothesis that there is no difference in biodiversity between herbicide-tolerant transgenic crops and conventional crops. In particular, the study was aimed at examining implications to farmland biodiversity in the event of large-scale commercial introduction of herbicide-tolerant transgenic crops to the United Kingdom (Firbank et al., 2003). The study design was carried out over 3 years in 60 crop fields across England and Scotland. The crops tested were sugar beet, maize, and winter and spring oilseed rape, and the biodiversity recorded included the abundance of weeds and invertebrates. However, the FSE was tied to a rather narrow hypothesis test and constrained to a field scale (Freckleton et al., 2003).

The most serious limitation of the FSE from the standpoint of public policy is that the study has no predictive component. Forecasts of the likely impacts on biodiversity 10,20 , or even 50 years into the future and at the landscape level are needed if policy decisions are to be made in Europe (Freckleton et al., 2003). Although the FSE is extremely comprehensive, the results are not adequate to evaluate effectively the likely long-term impacts on biodiversity of growing herbicide-resistant transgenic crops. Because commercialization of transgenic crops is likely to have a range of effects on plant and invertebrate functional groups in the long term (Hawes et al., 2003), policy 
evaluations with the same time scale should be based on a modeling framework going beyond the local scale to embrace the whole farming community (Watkinson, Freckleton, Robinson, \& Sutherland, 2000).

The FSE suggested that transgenic herbicide-tolerant crops may benefit biodiversity because spraying of crops may be delayed until later in the growing season, allowing weeds to grow during the early part of the year. This provides an enhanced resource for arthropods and potential benefits for birds that feed on them. However, a review of weed phenologies and a population model recently showed that this benefit is unlikely to occur because spraying is generally delayed insufficiently late in the season to allow most of the weeds to set seed. An increase in weed biomass would therefore eventually translate into a reduction in the number of weed species. The positive effects on biodiversity observed in trials lasting one or two seasons are thus likely to be transient (Freckleton et al., 2004). However, some other impacts of transgenic crops on biodiversity do not appear to be transient at all.

The worldwide genetic homogenization of agroecosystems driven by the deployment of transgenic crops is an unprecedented reality (C. James, 2003a), and its consequences do not seem to be even comparable with those of the Green Revolution. A recent analysis compared samples of cultivated wheat (Triticum aestivum L.) collected between 1922 and 1971 in four geographical regions of Europe and Asia (Khlestkina et al., 2004). This study demonstrates that the level of genetic diversity was not significantly influenced within the almost 50-year period surveyed despite the introduction of modern high-yielding varieties obtained by conventional plant breeding. During just about 10 years of expansion, transgenic crops have led to an unprecedented agricultural homogenization that is already recognized to have high potential to threaten the genetic diversity of crops and wild relatives (St. Amand, 2004).

Crop-breeding strategies are highly dependent on preservation of diversity of crops and wild relatives. According to a recent $\mathrm{FAO} / \mathrm{WHO}$ report (FAO/WHO Secretariat, 2004), many methods of modern biotechnology can interfere with diversity of organisms that have relevance for further breeding. These methods can often concentrate on the further improvement of few elite crop lines only. As a consequence, the majority of locally adapted land races will not be propagated further. In addition, the system for protecting intellectual property rights on transgenic cultivars is likely to interfere with crop diversity. These considerations increase the current scientific and public concern about the current rapid decline of biodiversity (FAO/ WHO Secretariat, 2004).

The Mediterranean basin is a center of biodiversity, and many crop plants were domesticated in this area. Transgene exchanges pose major threats to Mediterranean agriculture because in centers of diversity, the probability for transgenic crops of finding sexually compatible wild relatives is very high (Altieri, 2001). The impacts go beyond genetic changes in heterogeneous native crop varieties to embrace effects on evolutionary processes such as gene flow between native crops and wild relatives (Altieri, 2003). In addition, expected metabolic changes due to the expression of transgenes in new genetic contexts are a key issue for Mediterranean agriculture, whose competitiveness is based on the quality and identity of local food (Istituto Nazionale di Ricerca per gli Alimenti e la Nutrizione $\&$ Ministero delle Politiche agricole e Forestali, 2004).

The EU is the world's largest wine producer, with more than one half of total world production (Eurostat, 2004) and is also a center of domestication of grape. The commercial release of transgenic grape will likely contribute to reduce the biodiversity of grape, already endangered by the worldwide expansion of a few popular cultivars, such as Chardonnay or CabernetSauvignon (Bouquet, Torregrosa, \& Chatelet, 2003). Transgenic grape will worsen the reduction of clonal variability in cultivars because only a very limited number of clones will be transformed. Furthermore, alternative tools of crop improvement are becoming available that explore the potential of natural biodiversity without using transgenic crops.

The recent approach of pyramiding beneficial wildspecies chromosome segments (a technique that enriches the genetic basis of cultivated plants with wild alleles via plant breeding) seems to provide a crop improvement alternative to the genetically modified organism strategy, offering a new paradigm to revitalize plant breeding. This alternative was shown in a recent experiment (Gur \& Zamir, 2004) where yield of hybrids parented by the pyramided genotypes was more than $50 \%$ higher than that of a control market leader variety, under both wet and dry field conditions. Conversely, it is known that crop yields were not measured in the described FSE study. Therefore, in 
Europe it is not possible to judge the effectiveness of transgenic crop technology and whether or not it delivers increased yields (Freckleton et al., 2003).

\section{Possible Effects on Human Health}

In general, there are many questions but few data on the potential health risks of food derived from transgenic crops, although research to exclude such risks should have preceded the introduction of transgenic crops into the food chain (Pusztai, Bardocz, \& Ewen, 2003). Risk assessment of foods derived from transgenic crops has a comparative approach based on the substantial equivalence between transgenic crops and their parental line crops (König et al., 2004). This approach has been proved to be a crude, poorly defined, and unscientific concept, experimentally contradicted even in term of macronutrients contents (Pusztai et al., 2003).

The fact that the cornerstone of the safety assessment of novel foods is the concept of substantial equivalence does not mean that this concept is suitable for the safety assessment of foods derived from transgenic crops (König et al., 2004); instead, no alternative approach has been proposed so far, whereas critics of the concept of substantial equivalence have repeatedly stressed the following points:

- This testing approach does not sufficiently address putative unintended and unexpected effects or potential long-term effects that result from sustained human exposure to transgenic crops because such crops might have subtle compositional changes that may be difficult to detect.

- There is a lack of detailed international standards guiding the choice of parameters to be measured in the comparative analysis and in the application of rigorous statistical analysis, reducing the quality of individual assessments.

The EU-sponsored European network safety assessment of genetically modified food (ENTRANSFOOD) project (Kuiper et al., 2004) was a multidisciplinary experience, which made it possible to jointly examine a broad range of relevant issues related to the risk assessment, management, and communication of transgeniccrop-derived foods. In the ENTRANSFOOD project, consensus was reached that a rigorous science-based risk assessment of the environmental impact and of possible effects on human health of foods derived from transgenic crops is not sufficient to gain public support for the introduction of this new food production technology into the society. Aspects such as sustainability, benefits, and impact on the society must also be taken into account.

Currently, the Cartagena Protocol on Biosafety to the Convention on Biological Diversity is the only international regulatory instrument that deals specifically with the potential adverse effects of genetically modified organisms on the environment (FAO/WHO Secretariat, 2004). In response to the increased delivery of transgenic crop-derived foods to international markets, the FAO/WHO Ad Hoc Intergovernmental Task Force on Food Derived From Biotechnology of the Codex Alimentarius Commission broadened the Codex risk assessment to include indirect effects of novel foods on the environment that may have an indirect impact on human health (Haslberger, 2003).

The FAO/WHO risk assessment broadening acknowledges that unanticipated effects may also arise from the expression of foreign genes in a new genetic background (Haslberger, 2003). Codex principles do not have a binding effect on national legislation but are referred to specifically in the Sanitary and Phytosanitary Agreement of the World Trade Organization (WTO) and can be used as a reference in case of trade disputes. This is particularly relevant to the recent complaint brought by the United States, Canada, and Argentina to the WTO against the EU de facto moratorium on transgenic crops.

\section{Risk Assessment: Does It Work?}

The risk assessment of transgenic crops focuses especially on potential consequences on the stability and diversity of ecosystems, including putative invasiveness, vertical or horizontal gene flow, other ecological impacts, effects on biodiversity, and the impact of presence of transgenic material in other products as food (Conner, Glare, \& Nap, 2003). But genetic engineering of crops is a new technology in its embryonic stages, and there are many other risks that cannot even be foreseen yet, because scientists still do not know enough about the way genes operate and interact in genetically engineered organisms to be confident of what the outcome of any modification will be (Bakshi, 2003).

Risk assessment has also its own intrinsic serious limitations because environmental risks are most easily assessed after damage has occurred, whereas risk assessment is useful for decision making only when 
the risks are assessed before damage actually occurs (Andow \& Hilbeck, 2004). For example, the environmental risks posed by the introduction of an exotic or nonindigenous species can be readily assessed after the species is established in a new environment. However, until recently there was no mandatory assessment of these risks before the introduction of a nonnative species. Even today, early risk assessments for the introduction of nonindigenous species are based on expert opinion rather than scientific fact (Andow \& Hilbeck, 2004). But where are we now in terms of scientific fact?

In the case of vertical gene flow, it appears that a lot of baseline data for the putative recipients of transgenes from transgenic crops are still missing, and without this, the possible short-term effects are difficult and long-term evolutionary success even impossible to predict (van Tienderen, 2004). This is why also in the case of transgenic crops risk assessment methods and their effectiveness are limited by large gaps in the scientific understanding of environmental and ecological processes, which create great uncertainties and undermine the predictive power of science in the analysis (Andow \& Hilbeck, 2004). However, the lack of scientific understanding is not the only level of constraint to reliable risk assessment of transgenic crops.

Because risk assessment is usually made on a comparative basis, the term of comparison has a key impact on the outcome of the assessment. The evaluation of risks must move beyond comparing transgenic fields and conventionally managed systems to include alternative cropping systems featuring crop diversity and low external-input approaches (Altieri, Gurr, \& Wratten, 2004). As a recent review pointed out (Hole et al., 2005), such alternative farming systems express higher levels of biological diversity and agroecosystem processes compared to conventional ones. In addition, the case-by-case analysis of the environmental impact of transgenic crops may have considerable merit as part of regulatory assessment, but it can lack vision about indirect effects of such crops on the environment (Dale et al., 2002).

Due to methodological and scientific gaps, it is virtually impossible to quantify or predict the long-term impacts resulting from widespread use of transgenic crops on biodiversity and on biodiversity-mediated processes (Altieri et al., 2004). Thus, it would be more sound to deepen the scientific foundations of an ecologically based strategy of ecosystem management. Such a strategy already has its own in-built sustainability since it has been tested over an evolu- tionary relevant time scale and therefore hardly needs a risk assessment. This would save huge resources in terms of the cost of both risk assessment and the remediation in case of environmental pollution.

Specifically, the deployment of transgenic crops in the Mediterranean area (particularly in Italy) poses very serious concerns, because

- the high biological diversity resulting from the high variability of environmental factors on relatively small areas would significantly decrease the spatial validity of any environmental risk study, making the cost of risk assessment for transgenic crops prohibitive;

- there is general consensus on the fact that environmental risk of transgenic crops would be acceptable just in lowland agricultural systems characterized by large farms, which is not the case of the majority of Mediterranean agriculture;

- the Mediterranean basin is the center of domestication of many crops and hosts a wide variety of ancestors of domesticated plants as well as botanically related wild species, so the risk of gene flow is potentially very high (Istituto Nazionale di Ricerca per gli Alimenti e la Nutrizione \& Ministero delle Politiche agricole e Forestali, 2004).

During the past 15 years, more than 81 international research projects related to the biosafety of transgenic crops have been supported by the EU. These projects have involved more than 400 teams from many different disciplines and represent a combined community financial contribution of about 70 million Euros (Saeglitz \& Bartsch, 2003). But because laboratory and field biosafety studies can only target a limited number of species and parameters, broad and longterm monitoring programs are indicated to detect potential side effects of transgenic crops. Who is going to pay for such broad long-term monitoring under the current scarcity of public funding for research? Rather, the cost of risk assessment and monitoring should be part of a cost-benefit evaluation comparing transgenic crops to other options.

\section{Precautionary Implications}

Through the precautionary principle, governments acknowledge the limits of science as a basis for policy while seeking to clarify scientific uncertainty: this ten- 
sion is exemplified by the European risk regulation of transgenic crops (Levidow, 2001). Invoking the precautionary principle, regulatory procedures delayed or restricted commercial use of transgenic crops and at the same time stimulated the accumulation of knowledge about uncertainties. When research methods of risk assessment were challenged, fact/value boundaries were blurred, thus increasing uncertainty. In this way, the risk controversy originated by divergent accounts of the relevant scientific uncertainty so uncertainty was constitutive and not merely contextual. In general then, precaution offers a means to justify uncertainty, not simply vice versa.

A precautionary approach is fundamental to both the Cartagena Protocol and to EU regulations, whereas it is ancillary to the United States oversight system (Andow \& Hilbeck, 2004). The application of the precautionary principle in EU regulation on transgenic crops reflects the growing risk aversion among consumers, already heightened by a series of recent threats to public health arising from problems allegedly caused by increasingly "industrial" approaches to food production (Lubbock \& Coop, 2002). But beyond consumer acceptance, advocates of biotechnology face political and social challenges too. In fact, the controversy on transgenic crops also reflects issues of globalization, American hegemony, economic concentration, and the increasing dependence of agriculture on technology (Arntzen et al., 2003).

The evaluation of technological options with respect to their risks and benefits is not only a scientific question. This insight has led to the recent development of a participatory approach to technology assessment (Skorupinski, 2002): in the light of the precautionary principle, a new technology cannot be declared innocent until proven guilty, and ethical questions, arising on how to weigh the burden of evidence in case of risky decisions, can only be answered in the course of public deliberation. There is a need to find ways of helping people to participate in this contemporary society as more than consumers and the debate needs to be redemocratized so that values other than purely scientific and technological ones can be injected into the deliberating process (Hunt, 2004). But what is the public perception of the risks related to transgenic crops?

When focusing on a concern for the long-term or possible chronic impacts of biotechnology, it might be more accurate to talk about public perceptions of uncertainty rather than public perceptions of risk. Many, perhaps most, significant disputes about the use of science and technology in society center on issues of ethics, equity, justice, and how to choose the most prudent collective course of action, not necessarily on the science itself (Priest, 2001). In Europe, fewer than 1 in 20 trust national public bodies, and only 1 in 100 trust industry to tell them the truth about transgenic crops (Gaskell, Bauer, Durant, \& Allum, 1999). This distrust is the root of the public opposition to the introduction of transgenic crops in the EU.

Many other factors outside of the technology itself influence the public understanding of transgenic crop technology. Perceptions the general public has about biotechnology, particularly genetic modification, have been widely researched (e.g., the PABE study_Public Perceptions of Agricultural Biotechnologies in Europe; Hunt, 2004). People's perceptions of risk were found mainly to center around certain perceived qualities of risk such as how much choice could be exercised over the use of a biotechnology, what was the benefit compared to the risk, and the anxiety about potential negative impacts on health and the environment. Such public perceptions of agricultural biotechnologies are able to influence the debate about transgenic crops.

The extent to which the public perception of transgenic crops reflects scientific evidence also depends on the flow of information between experts and nonexperts. Therefore, debates about new technologies, such as crop and food genetic modification, usually raise pressing questions about the ways experts and nonexperts communicate. A European study made use of 50 hours of in-depth interviews with genetic engineering scientists, nonexperts, and other stakeholders in the transgenic crops debate to examine this phenomenon (Cook, Pieri, \& Robbins, 2004). This study uncovers rhetorical devices used by scientists to characterize and ultimately undermine participation by nonexperts in areas including rationality, knowledge, understanding, and objectivity. A conclusion was drawn that scientists engage with the public from their own linguistic and social domain, without reflexive confirmation of their own status as part of the public and the citizenry.

The historical relationship between public/ academic scientists and the public is in general one of trust because the public provides funds for the scientific community with the expectation that they will not abuse their trust and they will be self-regulating and work for the common good. However, the merging of academic science and private industry complicates this relationship. For example, research universities in 
the United States are now quasi businesses that increasingly depend on scientific research that can be patented for funding, creating suspicions of conflict of interest (Scott, 2003). Yet in Europe, some politicians, administrators, and scientists feel that the current degree of separation between public/academic science and industry is causing the EU to fall behind the United States in reaping the economic benefits of science (Scott, 2003). However, the short-term economic benefits from merging the academy with industry come at the price of subverting reasonable, democratic discourse aimed at the common good and ecological health and integrity.

Controversies about genetically modified foods in the EU highlight the apparent differences that exist in public opinion on this subject across the Atlantic (Gaskell et al., 1999). Concern over the impact on the safety of the food supply remains low in the United States but is substantially elevated in Europe (Falk et al., 2002). This divergence reflects the regulatory approaches of the United States and the EU in the area of agricultural biotechnology and can also be explained by examining how international pressure for change is filtered through and sometimes subverted by the domestic political economy (Prakash \& Kollman, 2003). As the case of United States/EU regulation divergence demonstrates, globalization has complex dynamics and also creates the potential for the use of its own underpinning key principles, such as transparency (e.g., labeling-related issues), to contrast global market-driven trends (Prakash \& Kollman, 2003).

The EU regulatory approach on transgenic crops leans heavily on transparency and consumer choice as a means to rebuild confidence in a regulatory system, the credibility of which has been severely damaged (Arntzen et al., 2003). Recent issues such as BSE (Bovine Spongiform Encephalopathy) and foot-andmouth disease raised questions about food safety, increasing the profile of questions relating to how food is produced. In addition, as also evident in other countries (Yamaguchi \& Harris, 2004), the evaluation of a new agricultural technology is both a material conflict over how food and fiber will be produced and a symbolic contest over which view of agriculture will prevail. It is therefore important that the future use of biotechnology in agriculture is considered in the context of a broader discussion about our vision for agriculture and the environment over the coming decades (Dale, 2002).

European regulators have initiated the process of trying to incorporate socioeconomic factors into the regulatory process, with Denmark leading this process (Myhr \& Traavik, 2003b). The control of transgenics is held by a handful of multinationals, and this makes many people very uneasy, due in part to previous experiences of dealing with multinationals following environmental disasters (Myhr \& Traavik, 2003a). In addition to this, European consumers are still not convinced that the benefits from herbicide-tolerant and insect-resistant crops outweigh the risks, especially the environmental risk, because the present generation of transgenic crops gives only marginal benefits, and the risks are perceived as not worth taking (Arntzen et al., 2003). All it will take to cut the thread of social trust is to have a regulator or a private company employee say, "Oh no! What have we done?" (Smyth, 2003).

Societal dialogue and scrutiny should accompany and guide the development of modern agricultural biotechnology in the EU (EU-Commission, 2002a). The relationship between science, technology, and innovation on the one hand and society on the other must be reconsidered, and science activities need to center around the needs and aspirations of Europe's citizens to a greater extent (EU-Commission, 2002b). Besides, the European Union government itself acknowledges that transgenic crops may have adverse effects on the conservation and sustainable use of biological diversity and on human health (EU-Council, 2002). Nevertheless, pressure coming from outside the EU is currently threatening a structured societal dialogue and scrutiny on transgenic crops.

The United States, Canada, and Argentina have decided to challenge the moratorium on commercial transgenic food and crops introduced in Europe in 1999 (GeneWatch-UK, 2003) — and this despite the fact that the European approach is consistent with international regulations as the WHO/FAO Codex guidelines and the Cartagena Protocol. But the three countries mentioned are the largest producers of transgenic crops, so they also have the most to lose from restrictions on trade in such crops. They are claiming that Europe's approach discriminates against them unfairly and have made their challenge at the WTO. The outcome of this case will not only have impacts on Europe but also on whether other countries can regulate transgenic crops and foods as their citizens think best.

A feature of Western ethical and political thought has been the emphasis given to universal principles in guiding human conduct. In this context, a global rather than a local or national, a specific rather than a generic 
or industry-based code of ethics is a new concept that arises from a realization that conflicts emanating from divergent values, interests, and capacities cannot be resolved on the basis of scientific and economic power and reasoning alone (Gesche, Haslberger, \& EntsuaMensah, 2004).

\section{Alternatives to Transgenic Crops}

The alternative between transgenic and nontransgenic crops is real only if the two options are able to remain distinct while coexisting. If planting transgenic crops prevents the distinct existence of other alternative technologies, there is no real choice. The Joint Research Centre (the institutional research center of the European Union) published the report of a study on agronomic and economic aspects of coexistence of transgenic, conventional, and organic crops in European agriculture (Bock, Lheureux, LibeauDulos, Nilsagård, \& Rodriguez-Cerezo, 2002). From this report, it is clear that coexistence in the same region with tolerance thresholds of $0.1 \%$ is virtually impossible. When considering more relaxed thresholds of $0.3 \%$ for production of seed and $1 \%$ for food and feed production, coexistence of transgenic and nontransgenic crops in a region (with $10 \%$ or $50 \%$ transgenic share) might technically be possible but economically difficult because of the costs and complexities of changes associated.

Particularly difficult would be the coexistence of transgenic crops and organic agriculture because the latter does not tolerate transgenic crop use (Haslberger, 2003). Organic farming is the only form of agriculture that is legally defined in the EU (Atkinson, Litterick, Walker, Walker, \& Watson, 2004). A fundamental difference between the management of organic and conventional systems is the way in which problems are approached. Conventional agriculture mostly relies on targeted solutions, whereas organic production normally relies on solutions implemented at a system level. The targeted approach of modern agricultural biotechnology together with ethical and safety concerns have persuaded organic farmers that transgenic crops are inconsistent with their ecological strategy.

The land area under organic management has increased continually since the mid-1980s throughout the EU, and now almost all European governments provide strong political support to organic farming through specific national plans (Willer \& Yussefi, 2004). According to the Swiss Research Institute of Organic Agriculture (2003), by the end of 2002 in the
15 countries of the EU, around 4.8 million hectares were managed organically by almost 140,000 farms. In 2003, numerous organic farming-related research projects were funded under the first call of the sixth framework program, the main research funding scheme in the EU. Therefore, EU acknowledges the potential ecological benefits of organic farming as opposed to conventional agriculture whose negative impact on farmland biota is not new.

The overall increase in homogeneity across the European farming landscape during the latter half of the 20th century has had a profoundly negative impact on farmland biota (Benton, Vickery, \& Wilson, 2003; Robinson \& Sutherland, 2002). The introduction of transgenic crops will further exacerbate the landscape homogenization driven by conventional agriculture (Altieri, 2000). On the other hand, according to a recent Italian analysis (Pacini, Wossink, Giesen, \& Huirne, 2004), organic farming systems are environmentally more beneficial than conventional farming systems. The experimental evidence also suggests that species abundance and/or richness across a wide range of taxa tend to be higher on organic farms than on conventional farms (Hole et al., 2005). Through its agricultural rural development policy, the EU is embracing a nonindustrial view of agriculture by providing support to more agroecological and biodiversity-friendly agricultural practices.

Given the negative impacts of agricultural homogenization, the current Common Agricultural Policy (CAP) of the EU aims to achieve an agriculture that is not only more competitive and profitable but also ecologically and environmentally sustainable (Walford, 2003). Since the mid-1980s, the CAP has been reformed to reverse a well-known European trend to agricultural overproduction. The CAP currently supports organic farming with subsidies in various ways: agroenvironmental programs, investment subsidies, marketing subsidies, and regional development and educational farms (Willer \& Yussefi, 2004). This new trend is in sharp contrast with a targeted productionoriented technology as transgenic crops are. The last thing that EU agriculture needs today is an increased food production. Beyond the CAP, this EU vision of a diversified and multifunctional agriculture and rural development is expressed in other important European policies.

The Pan-European Biological and Landscape Diversity Strategy (PEBLDS; http://www.strategyguide.org/) is the Pan-European response to the Convention on Biological Diversity and presents an innovative and 
proactive approach to stop and reverse the degradation of biological and landscape diversity values in Europe. The PEBLDS was endorsed in 1995 by 54 countries at the third Pan-European Conference of Ministers of the Environment. This strategy recognizes the vital role of agriculture for the management of landscapes and seminatural habitats as well as for maintenance of biological diversity and also stimulates a wiser management of agricultural land through organic farming methods. Because transgenic crops are likely to increase agricultural homogenization and to negatively impact biodiversity, their introduction in the EU in not coherent with the vision of agriculture expressed both in the CAP and in the PEBLDS.

In the CAP, sustainability is defined as more than the effective conservation and regeneration of natural resources because it also involves the contribution of farming to rural development. As farms are disappearing in the EU at a rate of about 120,000 units per year (Eurostat, 2004), larger farms are being run by fewer European citizens. In both developing and developed countries, small farms are more productive and more efficient and also contribute more to economic development compared to large farms (Rosset, 1999). In addition, small farms also perform better in terms of stewardship of natural resources and conservation of biodiversity. The recently introduced so-called second pillar of the CAP has a special focus on sustainable rural development and can be interpreted as an attempt to stop the steady decline in the number of smaller sized farms (Rickard, 2004). Transgenic crops fit best large farms as opposed to agroecological approaches that can benefit also medium to large European farmers involved in commercial agriculture (Altieri, 2001).

\section{Conclusions}

Although the global area of transgenic crops continues to grow at a sustained double-digit growth rate, this new agricultural biotechnology still encounters considerable resistance in the EU. This is mainly due to EU citizens' concerns about possible long-term adverse effects on the environment and human health but also to doubts of the sustainability of transgenic crops. Recent experimental evidence reinforces concerns and doubts on transgenic crops, particularly in the EU context. If sustainable agriculture has to be sought in Europe, three main goals have to be integrated: environmental health, economic profitability, and socioeconomic equity (Sustainable Agriculture
Research and Education Program, 1997). It is like a chair with three legs: If one breaks it, is not sustainable.

Increasingly, research is showing that transgenic crops have negative environmental impacts that are even potentially higher in the EU. On one hand, the landscape and regional dimension of vertical gene flow make almost impossible the coexistence of transgenic crops with organic farming, which has the potential to address the recent loss of biodiversity within European landscape. On the other hand, successful strategies of sustainable rural development in the EU such as ecological networks enhance pollenmediated gene flow preventing an effective transgene containment. In addition, Europe hosts many wild relatives of crops that have been genetically engineered for the market (e.g., oilseed rape, sugar beet, creeping bentgrass, alfalfa).

The deployment of transgenic crops does not appear economically profitable in Europe. A recent study analyzing the case of herbicide-tolerant sugar beet assessed whether the EU's de facto moratorium on transgenic crops was correct from a cost-benefit perspective (Demont, Wesseler, \& Tollens, 2004). By using the possible annual irreversible costs of herbicide-tolerant sugar beet, this study shows that the decision was correct. Furthermore, there are no data available on whether transgenic crops deliver increased yields in Europe. However, the evaluation of technological options with respect to their risks and benefits is not only a scientific and technical question. This insight has led to the recent development of a participatory approach to technology assessment.

According to the EU government, societal dialogue and scrutiny should guide the development of modern agricultural biotechnology in Europe because of a substantially elevated concern over transgenic crops in European countries. Transgenic crops are also developed largely for profit motives (Altieri et al., 2004), thus serving a private interest rather than a public one. In addition, as biological materials are increasingly being used as industrial commodities, questions of social and economic justice arise (Parry, 2004). European regulators have initiated the process of trying to incorporate such socioeconomic issues into the regulatory process by incorporating the precautionary principle in the regulations on transgenic crops.

From the present literature review, transgenic crops are not a suitable tool for sustainable agriculture in the EU due to specific environmental, economic, and socioeconomic reasons (Table 1). Until proper testing 
Table 1. Specific Reasons Why Transgenic Crops Have a Potentially Greater Adverse Impact on Sustainable Agriculture in the European Union Context Than Elsewhere

\section{Europe-Specific Concerns on the Introduction} of Transgenic Crops in Europe

Environmental-Very high potential impact on biodiversityrich European agriculture

Economic-Prohibitive cost of risk assessment, whereas economic advantages not proven yet in Europe

Socioeconomic_-Conflict with European nonindustrial and multifunctional vision of agriculture

on transgenic crops is completed, a moratorium on transgenic crops based on the precautionary principle should be officially adopted. However, an increasing amount of experimental molecular evidence (Kumar, Mills, Anderson, \& Mattoo, 2004) is providing an informative knowledge base in favor of alternative and more sustainable farming practices (e.g., organic farming). Therefore, there is no rationale in primarily devoting public research to test the safety of industrial commodities such as transgenic crops, thus serving a private interest rather than a public one.

\section{References}

Accinelli, C., Screpanti, C., Vicari, A., \& Catizone, P. (2004). Influence of insecticidal toxins from Bacillus thuringiensis subsp. Kurstaki on the degradation of glyphosate and glufosinate-ammonium in soil samples. Agriculture, Ecosystems and Environment, 103, 497-507.

Altieri, M. A. (2000). The ecological impacts of transgenic crops on agroecosystem health. Ecosystem Health, 6, 13-23.

Altieri, M. A. (2001). Genetically engineered crops: Separating the myths from the reality. Bulletin of Science, Technology \& Society, 21, 130-146.

Altieri, M. A. (2003). The sociocultural and food security impacts of genetic pollution via transgenic crops of traditional varieties in Latin American centers of peasant agriculture. Bulletin of Science, Technology \& Society, 23, 350-359.

Altieri, M. A., Gurr, G. M., \& Wratten, S. D. (2004). Genetic engineering and ecological engineering: A clash of paradigms or scope for synergy? In G. M. Gurr, S. D. Wratten, \& M. A. Altieri (Eds.), Ecological engineering for pest management: Advances in habitat manipulation for arthropods (pp. 13-31). Collingwood, Australia: CSIRO Publishing.

Altieri, M. A., Nicholls, C. I., \& Ponti, L. (2003). Biodiversità e controllo dei fitofagi negli agroecosistemi [Biodiversity and pest management in agroecosystems]. Firenze, Italy: Accademia Nazionale Italiana di Entomologia.

Andow, D. A., \& Hilbeck, A. (2004). Science-based risk assessment for nontarget effects of transgenic crops. BioScience, 54, 637-649.
Arntzen, C. J., Coghlan, A., Johnson, B., Peacock, J., \& Rodemeyer, M. (2003). GM crops: Science, politics and communication. Nature Reviews Genetics, 4, 839-843.

Atkinson, D., Litterick, A. M., Walker, K. C., Walker, R., \& Watson, C. A. (2004). Crop protection: What will shape the future picture? Pest Management Science, 60, 105-112.

Bakshi, A. (2003). Potential adverse health effects of genetically modified crops. Journal of Toxicology and Environmental Health Part B, 6, 211-225.

Benton, T. G., Vickery, J. A., \& Wilson, J. D. (2003). Farmland biodiversity: Is habitat heterogeneity the key? Trends in Ecology \& Evolution, 18, 182.

Bock, A.-K., Lheureux, K., Libeau-Dulos, M., Nilsagård, H., \& Rodriguez-Cerezo, E. (2002). Scenarios for co-existence of genetically modified, conventional and organic crops in European agriculture. Retrieved January 28, 2005, from http:// www.jrc.cec.eu.int/download/GMCrops_coexistence.pdf

Bouquet, A., Torregrosa, L., \& Chatelet, P. (2003). Grapevine genetic engineering: Tool for genome analysis or plant breeding method? Which future for transgenic vines? AgBiotechNet, 5 , $1-10$.

Brooks, D. R., Bohan, D. A., Champion, G. T., Haughton, A. J., Hawes, C., Heard, M. S., et al. (2003). Invertebrate responses to the management of genetically modified herbicide-tolerant and conventional spring crops. I. Soil-surface-active invertebrates. Philosophical Transactions of the Royal Society of London B, 358, 1847-1862.

Bruinsma, M., Kowalchuk, G. A., \& van Veen, J. A. (2003). Effects of genetically modified plants on microbial communities and processes in soil. Biology \& Fertility of Soils, 37, 329-337.

Chilcutt, C. F., \& Tabashnik, B. E. (2004). Contamination of refuges by Bacillus thuringiensis toxin genes from transgenic maize. Proceedings of the National Academy of Sciences of the United States of America, 101, 7526-7529.

Ching, L. L. (2004). Europe still resisting GMOs (Institute of Science in Society press release). Retrieved January 30, 2005, from http://www.i-sis.org.uk/ESRG.php

Chowdhury, E. H., Kuribara, H., Hino, A., Sultana, P., Mikami, O., Shimada, N., et al. (2003). Detection of corn intrinsic and recombinant DNA fragments and Cry $1 \mathrm{Ab}$ protein in the gastrointestinal contents of pigs fed genetically modified corn Bt11. Journal of Animal Science, 81, 2546-2551.

Conner, A. J., Glare, T. R., \& Nap, J.-P. (2003). The release of genetically modified crops into the environment. Part II. Overview of ecological risk assessment. Plant Journal, 33, 19-46.

Cook, G., Pieri, E., \& Robbins, P. T. (2004). "The scientists think and the public feels": Expert perceptions of the discourse of GM food. Discourse Society, 15, 433-449.

Dale, P. J. (2002). The environmental impact of genetically modified (GM) crops: A review. Journal of Agricultural Science, 138, 245-248.

Dale, P. J., Clarke, B., \& Fontes, E. M. G. (2002). Potential for the environmental impact of transgenic crops. Nature Biotechnology, 20, 567-574.

Demont, M., Wesseler, J., \& Tollens, E. (2004). Biodiversity versus transgenic sugar beet: The one euro question. European Review of Agricultural Economics, 31, 1-18.

Dunfield, K. E., \& Germida, J. J. (2004). Impact of genetically modified crops on soil- and plant-associated microbial communities. Journal of Environmental Quality, 33, 806-815. 
EU-Commission. (2002a). Lifesciences and biotechnology- $A$ strategy for Europe. Brussels, Belgium: European Commission.

EU-Commission. (2002b). Science and society action plan. Luxembourg: Office for Official Publications of the European Communities.

EU-Council. (2002). Council decision of 25 June 2002 concerning the conclusion, on behalf of the European Community, of the Cartagena Protocol on Biosafety. Official Journal of the European Communities, 45, 48-65.

Eurostat. (2004). Eurostat yearbook 2004: The statistical guide to Europe. Luxembourg: European Communities.

Falk, M. C., Chassy, B. M., Harlander, S. K., Hoban, T. J., McGloughlin, M. N., \& Akhlaghi, A. R. (2002). Food biotechnology: Benefits and concerns. Journal of Nutrition, 132, 1384-390.

Firbank, L. G. (2003). Introduction. Philosophical Transactions of the Royal Society of London B, 358, 1777-1778.

Firbank, L. G., Heard, M. S., Woiwod, I. P., Hawes, C., Haughton, A. J., Champion, G. T., et al. (2003). An introduction to the Farm-Scale Evaluations of genetically modified herbicidetolerant crops. Journal of Applied Ecology, 40, 2-16.

Food and Agriculture Organization/World Health Organization Secretariat. (2004). Emerging risks related to the environment and new technologies. Retrieved May 3, 2005, from http:// www.fao.org/docrep/meeting/008/j3255e/j3255e00.htm

Frankham, R., Ballou, J. D., \& Briscoe, D. A. (2002). Introduction to conservation genetics. Cambridge, UK: Cambridge University Press.

Freckleton, R. P., Stephens, P. A., Sutherland, W. J., \& Watkinson, A. R. (2004). Amelioration of biodiversity impacts of genetically modified crops: Predicting transient versus long-term effects. Proceedings of the Royal Society of London-Series B: Biological Sciences, 271, 325-331.

Freckleton, R. P., Sutherland, W. J., \& Watkinson, A. R. (2003). Deciding the future of GM crops in Europe. Science, 302, 994996.

Gaskell, G., Bauer, M. W., Durant, J., \& Allum, N. C. (1999). Worlds apart? The reception of genetically modified foods in Europe and the U.S. Science, 285, 384-387.

GeneWatch-UK. (2003). The GM dispute at the WTO: Forcing GM foods on Europe? (Briefing No. 25). Retrieved January 2, 2005, from http://www.genewatch.org/Publications/Briefs/ brief25.pdf

Gepts, P., \& Papa, R. (2003). Possible effects of (trans)gene flow from crops on the genetic diversity from landraces and wild relatives. Environmental Biosafety Research, 2, 89-103.

Gesche, A., Haslberger, A., \& Entsua-Mensah, R. M. (2004). Towards a global code of ethics for modern foods and agricultural biotechnology. In J. Tavernier \& S. Aerts (Eds.), EurSafe 2004, 5th Congress of the European Society for Agricultural and Food Ethics (pp. 125-128). Leuven, Belgium: Katholieke Universiteit Leuven.

Groot, A. T., \& Dicke, M. (2002). Insect-resistant transgenic plants in a multi-trophic context. Plant Journal, 31, 387-406.

Guéritaine, G., Bazot, S., \& Darmency, H. (2003). Emergence and growth of hybrids between Brassica napus and Raphanus raphanistrum. New Phytologist, 158, 561-567.

Gur, A., \& Zamir, D. (2004). Unused natural variation can lift yield barriers in plant breeding. PLoS Biology, 2, e245.
Hails, R., \& Kinderlerer, J. (2003). The GM public debate: Context and communication strategies. Nature Reviews Genetics, 4, 819-825.

Halford, N. G. (2004). Prospects for genetically modified crops. Annals of Applied Biology, 145, 17-24.

Haslberger, A. G. (2003). Codex guidelines for GM foods include the analysis of unintended effects. Nature Biotechnology, 21, 739-741.

Hawes, C., Haughton, A. J., Osborne, J. L., Roy, D. B., Clark, S. J., Perry, J. N., et al. (2003). Responses of plants and invertebrate trophic groups to contrasting herbicide regimes in the farm scale evaluations of genetically modified herbicide-tolerant crops. Philosophical Transactions of the Royal Society of London B, 358, 1899-1913.

Haygood, R., Ives, A. R., \& Andow, D. A. (2004). Population genetics of transgene containment. Ecology Letters, 7, 213-220.

Heinemann, J. A., \& Traavik, T. (2004). Problems in monitoring horizontal gene transfer in field trials of transgenic plants. $\mathrm{Na}$ ture Biotechnology, 22, 1105-1109.

Hole, D. G., Perkins, A. J., Wilson, J. D., Alexander, I. H., Grice, P. V., \& Evans, A. D. (2005). Does organic farming benefit biodiversity? Biological Conservation, 122, 113-130.

Hunt, L. (2004). Factors determining the public understanding of GM technologies. AgBiotechNet, 6, 1-8.

Istituto Nazionale di Ricerca per gli Alimenti e la Nutrizione \& Ministero delle Politiche agricole e Forestali. (2004). Ricerche sugli organismi OGM in agricoltura: lavori in corsoSottoprogetto "Centro di Documentazione OGM" [Research in genetically modified organisms (GMO): Work in progressSubproject "GMO knowledge base"]. Retrieved May 3, 2005 , from http://inn.ingrm.it/Ricerca/OGM/ogm.htm

James, C. (2003a). Global review of commercialized transgenic crops. Current-Science, 84, 303-309.

James, C. (2003b). Global status of commercialized transgenic crops: 2003 (ISAA Briefs No. 30). Ithaca, NY: ISAAA.

James, P., Ashley, J., \& Evans, A. (2000). Ecological networks: Connecting environmental, economic and social systems? Landscape Research, 25, 345-353.

Jelenic, S. (2003). Controversy associated with the common component of most transgenic plants-Kanamycin resistance marker gene. Food Technology \& Biotechnology, 41, 183-190.

Khlestkina, E. K., Huang, X. Q., Quenum, F. J. B., Chebotar, S., Roder, M. S., \& Borner, A. (2004). Genetic diversity in cultivated plants-Loss or stability? Theoretical and Applied Genetics, 108, 1466-1472.

König, A., Cockburn, A., Crevel, R. W. R., Debruyne, E., Grafstroem, R., Hammerling, U., et al. (2004). Assessment of the safety of foods derived from genetically modified (GM) crops. Food \& Chemical Toxicology, 42, 1047-1088.

Kreyer, D., Oed, A., Walther-Hellwig, K., \& Frankl, R. (2004). Are forests potential landscape barriers for foraging bumblebees? Landscape scale experiments with Bombus terrestris agg. and Bombus pascuorum (Hymenoptera, Apidae). Biological Conservation, 116, 111-118.

Kuiper, H. A., Koenig, A., Kleter, G. A., Hammes, W. P., \& Knudsen, I. (2004). Concluding remarks. Food \& Chemical Toxicology, 42, 1195-1202.

Kumar, V., Mills, D. J., Anderson, J. D., \& Mattoo, A. K. (2004). An alternative agriculture system is defined by a distinct ex- 
pression profile of select gene transcripts and proteins. PNAS, $101,10535-10540$.

Levidow, L. (2001). Precautionary uncertainty: Regulating GM crops in Europe. Social Studies of Science, 31, 842-874.

Lubbock, M., \& Coop, A. (2002). A precautionary approach to genetic modification. Journal of Commercial Biotechnology, 8, 209-213.

Marchis, F. D., Bellucci, M., Arcioni, S., \& de Marchis, F. (2003). Measuring gene flow from two birdsfoot trefoil (Lotus corniculatus) field trials using transgenes as tracer markers. Molecular Ecology, 12, 1681-1685.

Martel, C., Rejasse, A., Rousset, F., Bethenod, M. T., \& Bourguet, D. (2003). Host-plant-associated genetic differentiation in Northern French populations of the European corn borer. $\mathrm{He}$ redity, 90, 141-149.

Marvier, M. (2000). Ecology of transgenic crops. RIS Biotechnology and Development Review, 3, 61-71.

Myhr, A. I., \& Traavik, T. (2003). Genetically modified (GM) crops: Precautionary science and conflicts of interests. Journal of Agricultural \& Environmental Ethics, 16, 227-247.

Myhr, A. I., \& Traavik, T. (2003). Sustainable development and Norwegian genetic engineering regulations: Applications, impacts, and challenges. Journal of Agricultural \& Environmental Ethics, 16, 317-335.

Obrycki, J. J., Losey, J. E., Taylor, O. R., \& Jesse, L. C. H. (2001). Transgenic insecticidal corn: Beyond insecticidal toxicity to ecological complexity. BioScience, 51, 353-361.

Pacini, C., Wossink, A., Giesen, G., \& Huirne, R. (2004). Ecologicaleconomic modelling to support multi-objective policy making: A farming systems approach implemented for Tuscany. Agriculture, Ecosystems \& Environment, 102, 349-364.

Parry, B. (2004). Trading the genome: Investigating the commodification of bioinformation. New York: Columbia University Press.

Poppy, G. M. (2004). Geneflow from GM plants-Towards a more quantitative risk assessment. Trends in Biotechnology, 22, 436438.

Prakash, A., \& Kollman, K. L. (2003). Biopolitics in the EU and the US: A race to the bottom or convergence to the top? International Studies Quarterly, 47, 617-641.

Priest, H. S. (2001). A grain of truth: The media, the public, and biotechnology. Lanham, MD: Rowman and Littlefield.

Pusztai, A., Bardocz, S., \& Ewen, S. W. B. (2003). Genetically modified foods: Potential human health effects In J. P. F. D'Mello (Ed.), Food safety: Contaminants and toxins (pp. 347372). Wallingford, UK: CABI Publishing.

Research Institute of Organic Agriculture. (2003). Organic farming in Europe. Retrieved May 3, 2005, from http://www. organic-europe.net/europe_eu/statistics.asp

Rickard, S. (2004). CAP reform, competitiveness and sustainability. Journal of the Science of Food and Agriculture, 84, 745-756.

Rieger, M. A., Lamond, M., Preston, C., Powles, S. B., \& Roush, R. T. (2002). Pollen-mediated movement of herbicide resistance between commercial canola fields. Science, 296, 23862388.

Robinson, R. A., \& Sutherland, W. J. (2002). Post-war changes in arable farming and biodiversity in Great Britain. Journal of Applied Ecology, 39, 157-176.
Rosset, P. (1999). The multiple functions and benefits of small farm agriculture in the context of global trade negotiations (Food First Policy Brief No. 4). Retrieved May 3, 2005, from http:// www.foodfirst.org/pubs/policybs/pb4.html.

Saeglitz, C., \& Bartsch, D. (2003). Regulatory and associated political issues with respect to Bt transgenic maize in the European union. Journal of Invertebrate Pathology, 83, 107-109.

Scott, D. (2003). Science and the consequences of mistrust: Lessons from recent GM controversies. Journal of Agricultural \& Environmental Ethics, 16, 569-582.

Sisterson, M. S., Antilla, L., Carriere, Y., Ellers-Kirk, C., \& Tabashnik, B. E. (2004). Effects of insect population size on evolution of resistance to transgenic crops. Journal of Economic Entomology, 97, 1413-1424.

Skorupinski, B. (2002). Putting precaution to debate-About the precautionary principle and participatory technology assessment. Journal of Agricultural \& Environmental Ethics, 15, 87102.

Smyth, S. (2003). Innovation and liability: "Oh no! What have we done?" AgBiotechNet, 5, 1-4.

Snow, A. A. (2002). Transgenic crops-Why gene flow matters. Nature Biotechnology, 20, 542.

St. Amand, P. (2004). Risks associated with genetically engineered crops In G. H. Liang \& D. Z. Skinner (Eds.), Genetically modified crops: Their development, uses, and risks (pp. 351-363). New York: Food Products Press.

St. Amand, P. C., Skinner, D. Z., \& Peaden, R. N. (2000). Risk of alfalfa transgene dissemination and scale-dependent effects. Theoretical and Applied Genetics, 101, 107-114.

Sustainable Agriculture Research and Education Program. (1997). What is sustainable agriculture? Retrieved November 27, 2004, from http://www.sarep.ucdavis.edu/concept.htm

van den Eede, G., Aarts, H. J., Buhk, H. J., Corthier, G., Flint, H. J., Hammes, W., et al. (2004). The relevance of gene transfer to the safety of food and feed derived from genetically modified (GM) plants. Food \& Chemical Toxicology, 42, 1127-1156.

van Tienderen, P. H. (2004). Hybridization in nature: Lessons for the introgression of transgenes into wild relatives In H. C. M. den Nijs, D. Bartsch, \& J. Sweet (Eds.), Introgression from genetically modified plants into wild relatives (pp. 7-25). Wallingford, UK: CABI Publishing.

Veronesi, F., \& Rosellini, D. (2002). Potential of biotechnology for alfalfa. AgBiotechNet, 4, 1-3.

Viard, F., Arnaud, J. F., Delescluse, M., \& Cuguen, J. (2004). Tracing back seed and pollen flow within the crop-wild Beta vulgaris complex: Genetic distinctiveness vs. hot spots of hybridization over a regional scale. Molecular Ecology, 13, 13571364.

Walford, N. (2003). Productivism is allegedly dead, long live productivism. Evidence of continued productivist attitudes and decision-making in South-East England. Journal of Rural Studies, 19, 491-502.

Watkinson, A. R., Freckleton, R. P., Robinson, R. A., \& Sutherland, W. J. (2000). Predictions of biodiversity response to genetically modified herbicide-tolerant crops. Science, 289 , 1554-1557.

Watrud, L. S., Lee, E. H., Fairbrother, A., Burdick, C., Reichman, J. R., Bollman, M., et al. (2004). Evidence for landscape-level, pollen-mediated gene flow from genetically modified creeping 
bentgrass with CP4 EPSPS as a marker. PNAS, 101, 1453314538.

Wilkinson, M. J., Elliott, L. J., Allainguillaume, J., Shaw, M. W., Norris, C., Welters, R., et al. (2003). Environmental escape of GM crops. Hybridization between Brassica napus and B. rapa on a national scale in the United Kingdom. Science, 302, 457459.

Willer, H., \& Yussefi, M. (2004). The world of organic agriculture: Statistics and emerging trends, 2004. Bonn: International Federation of Organic Agriculture Movements.

Wolfenbarger, L. L., \& Phifer, P. R. (2000). The ecological risks and benefits of genetically engineered plants. Science, 290, 2088-2093.

Yamaguchi, T., \& Harris, C. K. (2004). The economic hegemonization of Bt cotton discourse in India. Discourse \& Society, 15, 467-491.

Zhu, B., Lawrence, J. R., Warwik, S. I., Mason, P., Braun, L., Halfhill, M. D., et al. (2004). Stable Bacillus thuringiensis (Bt) toxin content in interspecific $\mathrm{F} 1$ and backcross populations of wild Brassica rapa after Bt gene transfer. Molecular Ecology, 13, 237-241.

Luigi Ponti was born in Sardinia (Italy), the second biggest island of the Mediterranean Sea, in 1973. He received a degree in agricultural sciences at University of Perugia, where he also gained a Ph.D. in agricultural entomology and was a research assistant. Recipient of an abroad grant from the Italian National Research Council, he is now a research fellow at the University of California, Berkeley, in the Insect Biology Division of the Department of Environmental Science, Policy and Management, where he conducts research on the effects of vegetational diversity on insect pest populations and associated natural enemies in agroecosystems. 